Myelography に必要な任意の角度で透視，撮影診断が 可能となった，又最小のスタッフで，検查時間も短縮で きたので，被曝管理上も有用であった。

\section{5. 福島医大附属病院における診断用管球の焦点の推移}

福島県立医科大学附属病院中央レントダン

$$
\text { 青山正勝・山口 临・上明 稔 }
$$

本院に於计る診断用 X線管の新規購入に対する目安と 焦点の荒れ叉は毠裂の状態を掌握するためX線管球焦点 をMTFで表わすこと沉って管球焦点の推移を知るこ とが出来るのではないかと思い実験を行いました。

今年度新らしく胸部用 $\mathrm{X}$ 線管球の購入と共に管球焦点 を直径 $0.15 \mathrm{~mm}$ の $\mathrm{Pb}$ ピソホールカメラを作成し毎月1 回現在まで半年ほどピンホール写真をMTFで表わして 見ました。実験結果は焦点に変化は潘とんど見られませ んでした：これれは固定陽極に比べ回転陽極は陽極面積 が著しく大きくなるために面積比に対するWが大きく固 定陽極の様に渑裂は入りにくいからだと思います，今後 子案験を続けて焦点変化を観察したいと思います。

\section{6. 福島県における撮影条件と被懪の現況}

福島県立医科大学

関場盛也・上四·稔・伊藤陸郎

宮城 勝・斉藤瑞男

被曝軽減の万策については多くの登表があり，医師会 の答申や技師会での啓蒙等が行なわれているが，各施設 で取り入れられているとは云い難い，福島県内の各施設 で調查した胸部撮影条件と被曝線量の関係について報告 する．管電压は52から $140 \mathrm{kV}$ に分布し，增感紙はFSか ら MS 級汇移行しているが，グリッドの有無，グリッド の谪性使用，増感紙等を考虑しないために線量を増加さ せている，管球容量务ら見ると $150 \mathrm{kV}$ 型使用施設が $71 \%$ で $90 \mathrm{kV}$ 以下の $62 \% か ゙ 150 \mathrm{kV}$ 型を使用していることから， 高庄化々付加フィルタ等を含めた撮影条件の再検討をす るならば，より被曝線量を軽減出来る余地があることが 分った。

\section{7. 近接実体 X 線写真撮影観察法}

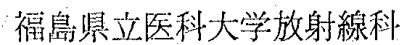

佐藤久夫・加藤和夫 $\cdot$ 遠藤 正 佐藤勝美

実体 $\mathrm{X}$ 線写真撮影観察法は，X線写真の射影幾何学的 特性と視覚現象の射影幾何学的特性と両眼視視差による 立体知覚を応用して X 線像を日常視覚同様な三次元的立 体として知覚する方法である。

今回の近接実体 X線写真撮影観察法は, 線源一フィル 么間距離を $50 \mathrm{~cm}$ と短くする事により網膜像を大きくし 被写体構造をより精密に知る事を目的とした。
この方法による利点は，

1）立体分解能が向上する。

2）縌膜像が大きい為被写体構造をより精密に知る事 ができる。

3）管球負荷が小さくなる：欠点としては，

1) 被曝線量が増大寸る．2)観察による眼の疲学が比較 的大である。

\section{8: カラーX線像の研究（リバーサルカラーフィルムに よる直接法)}

弘前大学医学附属病院放射線部 藤森 明・尾崎博…金沢隆太郎 久保田護・葛西二郎・沢田俊治 上田隆三

リバーサルカラーフィルムを用いて，カラーX線像の 值接法を検討した，ASA 感度1000カラーリバーサルフ イルムを，G4，MR400 の增感紙と各々組合せ，アル ミ階段を撮影し，コダック E 4 標準現像をした所 G 4 で は緑，MR400 では青の単色ではあるが，濃淡のある 階段像を得た，上記実験に基き生体の手を撮影した所， G 4 は緑，MR400 は青の濃淡像となった色数を多くす る目的で，レッド或いは，ラッテン OA で第 2 露光を 与えた，G 4 で手を撮影し，レッドで第 2 露光を与えた 場合，骨部は赤，軟部組織は橙となった。フィタをラ ッテンOAにした場合，骨部は黄，軟部組織は黄緑とな った．今後尼工夫，研究して行さたい。

\section{Grid の比較検討 [第 2 報]}

新潟目厚生連中央総合病院

笠原一良

[目的]

X線グリッドの性能を左右する因子としてばグリッド 比，グリッド密度，材質などが上げられます，特に材質 でも中間物質として木とアルミが用いられています，今 问この木とアルミの違い林 $2 ， 3$ 基礎的実験をし ましたので報告します。

[考察]

(1)中間物質が木とアルミ製では木の厅が同一黑化度を 得るに撮影条件を20\%少なく出来る。

(2)散乱線量比は低圧領域ではアルミの方が良く高庄で は木の方が良い。

(3)現出能は管電圧による違いはなく被写体が厚くなる と木の方が良い．

(4)グリッドの黒化度ムラの観察ではアルミ製はムラが なく木製では一般にどのメーカー製でもムラが多く出ま 乙た。

10. 乳房専用カセッテの試作についと 